\title{
Two Catlinite Pipe Fragments from the Womack Site, Lamar County, Texas
}

Jesse Todd

Unknown

Follow this and additional works at: https://scholarworks.sfasu.edu/ita

Part of the American Material Culture Commons, Archaeological Anthropology Commons, Environmental Studies Commons, Other American Studies Commons, Other Arts and Humanities Commons, Other History of Art, Architecture, and Archaeology Commons, and the United States History Commons

Tell us how this article helped you.

This Article is brought to you for free and open access by the Center for Regional Heritage Research at SFA ScholarWorks. It has been accepted for inclusion in Index of Texas Archaeology: Open Access Gray Literature from the Lone Star State by an authorized editor of SFA ScholarWorks. For more information, please contact cdsscholarworks@sfasu.edu. 
Two Catlinite Pipe Fragments from the Womack Site, Lamar County, Texas

Creative Commons License

(c) $)(1)$ (9)

This work is licensed under a Creative Commons Attribution-NonCommercial 4.0 International License 


\title{
Two CATlinite Pipe Fragments from the Womack Site, Lamar CounTy, TeXas
}

\author{
Jesse Todd
}

\begin{abstract}
Two catlinite pipe fragments from the Womack site in Lamar County, Texas are discussed as well as other catlinite pipe fragments on Caddo sites from Northeast Texas.
\end{abstract}

Two catlinite pipe fragments have been recovered from the Womack site (41LR1). A stem was recovered by A. T. Jackson and a bowl by R. K. Harris and others. The site is located on a high bluff overlooking the Red River in Lamar County, Texas, and probably was occupied somewhere between AD 1700 and 1730 (Harris et al. 1965).

Jackson (n.d.:3) found an unusual catlinite pipe on the surface of the Womack site and describes the pipe stem as bearing a thin knob 5/8 inches long and 3/8 inches high with three notches on its edge and a small hole at its base (Figure 1). He further states that the pipe is of the same form or type of catlinite pipe used by the Sioux.

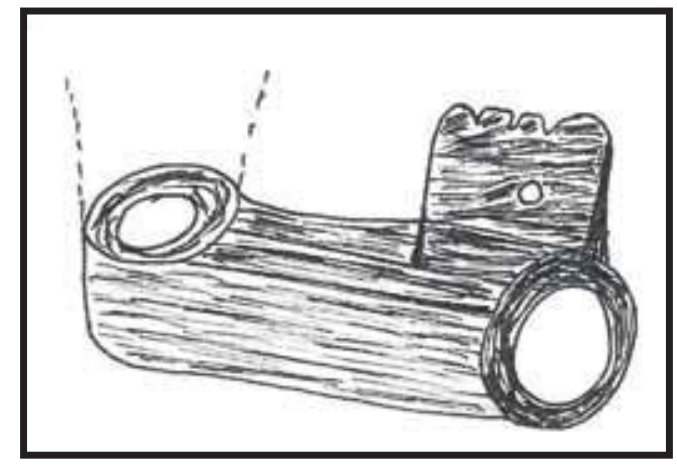

Figure 1. Catlinite pipe stem found by A. T. Jackson on the surface of the Womack site. Illustration from A.T. Jackson's notes provided by Ms. Laura Nightengale of the Texas Archeological Research Laboratory, The University of Texas at Austin.

The bowl that Harris et al. (1965:297) recovered during their testing of the site is shown in Figure 2. The bowl is $51 \mathrm{~mm}$ in long and the rim diameter is $26 \mathrm{~mm}$ (James Krakker, June 2008 personal communication). The pipe fragment probably is associated with the calumet because the pipe was made from red stone (catlinite) that forms a right angle elbow (Blakeslee 1981:763; Hall 1987:30). Blakeslee further states that catlinite pipes have a projecting prow but Brown (1989:325) illustrates calumet pipes that do not have the projecting prow.

According to Harrington (1920:271), the Caddo received Bénard de la Harpe at four villages along the Red River in 1719 with the calumet ceremony. Harris et al. (1965:357-360) provide evidence that the Womack site was one of the villages visited by la Harpe. The presence of French trade goods at the site tends to support that conclusion. Gilmore (1996:1-2) also discusses the presence of La Harpe at Caddo sites along the Red River, while Middlebrook (1994:32) and Perttula et al. (2004:96) discuss the use of the calumet by the Caddo. 

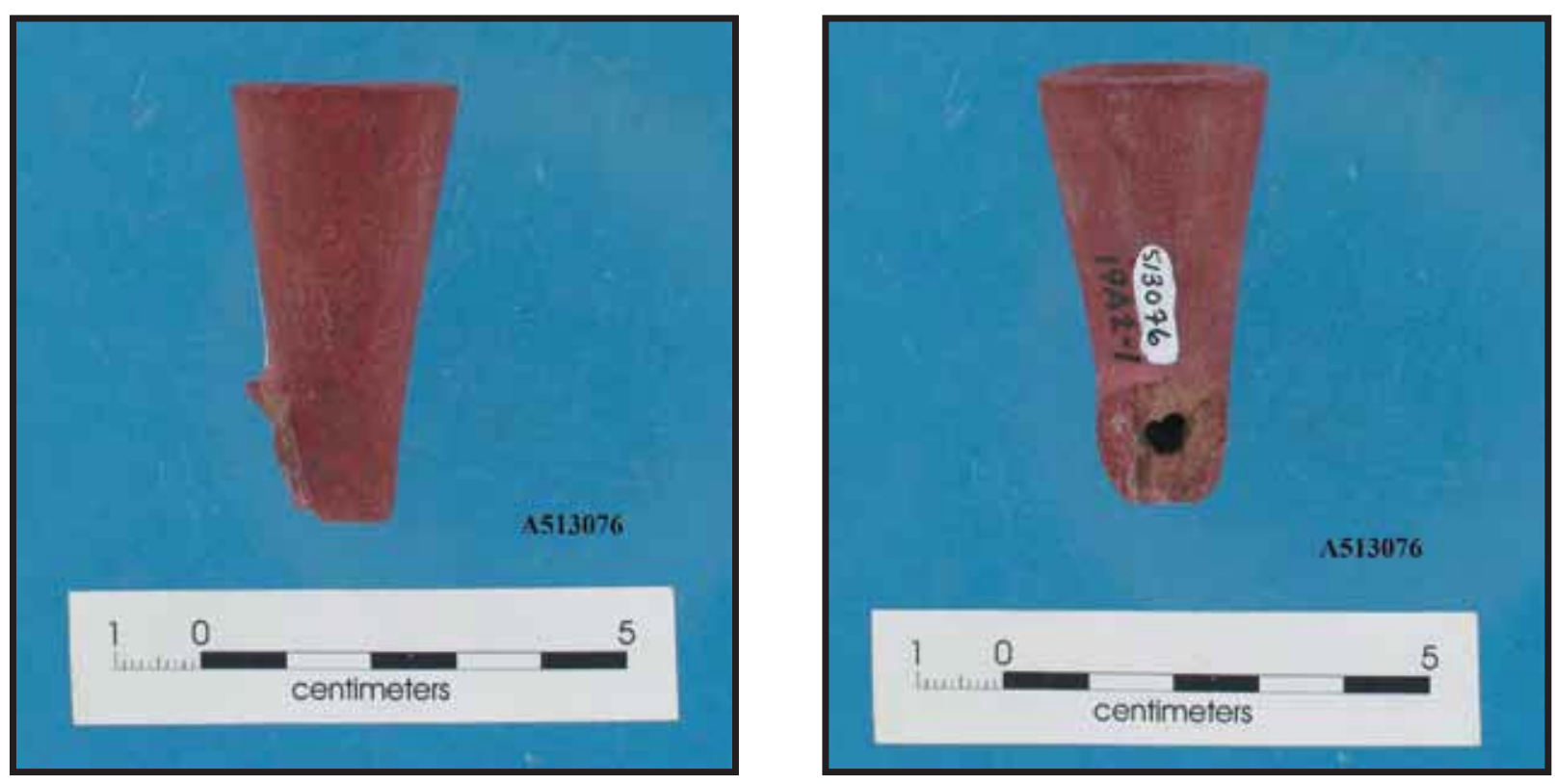

Figure 2. Catlinite pipe fragment from the Womack site. Left, profile of pipe bowl; Right, view from where stem would have been. Photo courtesy of Dr. James Krakker of the Smithsonian Institution.

At least two other catlinite pipe fragments have been discovered on historic Caddo sites in East Texas. A stem fragment was recovered from the Roseborough Lake site (41BW5) site in Bowie County, Texas (Miroir et al. 1973:124), and a bowl was recovered from 41 HO65 (Figure 3) in Houston County, Texas (Perttula et al. 2004:96-98). The catlinite pipe fragment from 41HO65 was analyzed using mineral spectroscopy and the results indicate that the pipe was made from catlinite found in quarries at the Pipestone National Monument in southwestern Minnesota.

The pipe stems from the Womack and 41H065 sites are similar, except for the nature of the thin knob. The knob from $41 \mathrm{HO} 65$ is irregular and angled whereas the one from the Womack site is square with three angled cuts.

It cannot be stated categorically that the catlinite pipes from the Womack site are calumet pipes. They simply may have been a trade item for personal use. However, the calumet ceremony was used by the Caddo and therefore, the pipes may have been a part of that ceremony. Hopefully, further archaeological investigations will uncover more evidence of the calumet ceremony in East Texas, thus providing additional evidence of interaction between the French and Caddo. 


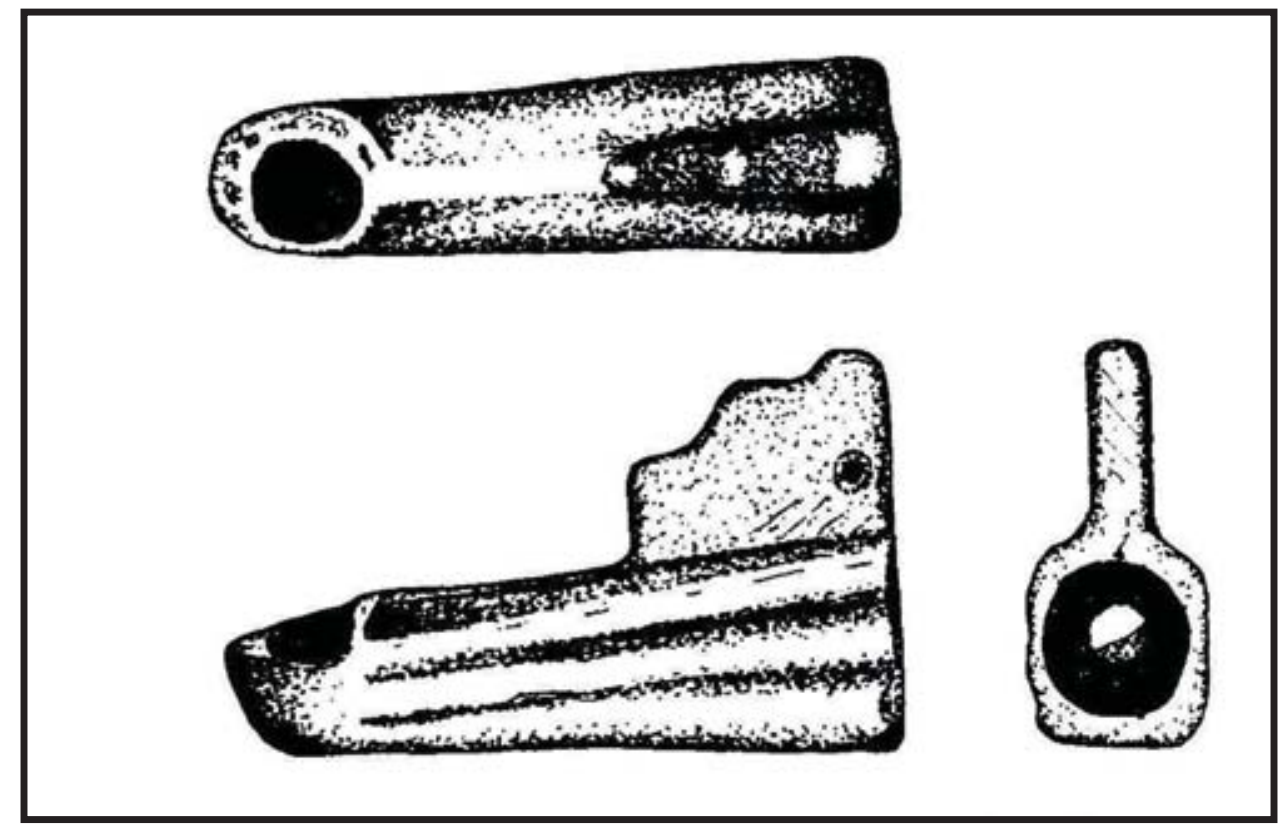

Figure 3. Catlinite pipe fragment from 41H065 (Perttula et al. 2004:98). Image reproduced courtesy of the Texas Archeological Society.

\section{Acknowledgments}

I would like to thank Dr. Tim Perttula for his patience, information, and help in preparing this paper. Also, I would like to thank the Texas Archeological Society for permission to use the illustration of the catlinite pipe from 41H065, Dr. James Krakker of the Smithsonian Institution for the photographs, and Laura Nightengale for the illustration from A. T. Jackson's notes.

\section{References Cited}

Blakeslee, Donald J.

1981 The Origin and Spread of the Calumet Ceremony. American Antiquity 46(4):759-768.

Brown, Ian W.

1989 The Calumet Ceremony in the Southeast and Its Archaeological Manifestation. American Antiquity 54(2):311-331.

Hall, Robert L.

1987 Calumet Ceremonialism, Mourning Ritual, and Mechanisms of Inter-Tribal Trade. In Mirror and Metaphor Material and Social Constructions of Reality, edited by Daniel W. Ingersoll, Jr. and Gordon Bronitsky, pp. 29-43. University Press of America, Lanham. 


\section{References Cited (Cont.)}

Gilmore, Kathleen

1996 Early European-Indian Ceremonies on the Red River. Journal of Northeast Texas Archaeology 7:1-2.

Harrington, M. R.

1920 Certain Caddo Sites in Arkansas. Museum of the American Indian, Heye Foundation, New York.

Harris, R. K. Inus Marie Harris, Jay C. Blaine, and Jerrylee Blaine

1965 A Preliminary Archeological and Documentary Study of the Womack Site, Lamar County, Texas. Bulletin of the Texas Archeological Society 36:287-363.

Jackson, A. T.

n.d. Notes from the excavation of the Womack Site. Information on file at the Texas Archeological Research Laboratory, The University of Texas at Austin.

Middlebrook, Tom

1994 An Update of Archaeological Investigations at the Tyson Site (41SY92). Journal of Northeast

Texas Archaeology 3:1-36.

Mirroir, M. P., R. King Harris, Jay C. Blaine and Janson McVay, with the collaborations by Donald C. Brook, Floyd Cicainero, Roger McVay, Joe B. Raffaelli, Jr., and Paul C. Shoen

1973 Benard De La Harpe and the Nassonite Post. Bulletin of the Texas Archeological Society 44:113168.

Perttula, Timothy K, Thomas E. Emerson, and Randall W. Hughes

$200441 \mathrm{HO64} / 65$, Late $17^{\text {th }}$ to Early $18^{\text {th }}$ Century Caddo Sites on San Pedro Creek in Houston County, Texas. Bulletin of the Texas Archeological Society 75:85-103. 